Рекомендована д. мед. наук, профр. О. М. Олещук

УДК 616-006-085.277.3:612.119:615.036.8

DOI 10.11603/2312-0967.2017.4.8335

\title{
ЕКСПЕРИМЕНТАЛЬНЕ ДОСЛІДЖЕННЯ СПЕЦИФІЧНОЇ ФАРМАКОЛОГІЧНОЇ АКТИВНОСТІ ПРЕПАРАТУ ПЕГ-ФІЛСТИМ
}

\author{
( В. Л. Карбовський, І. А. Шевчук, О. В. Куркіна \\ ТОВ «Фармацевтичний завод «Біофрарма»», Біла Церква \\ publication@biofarma.ua
}

\begin{abstract}
Мета роботи. Дослідити специфічну фрармакологічну активність препарату ПЕГ-Філстим на моделі феебрильної нейтропенії у мишей.

Матеріали і методи. Експериментальну лейкопенію в самців мишей лінії C57BL/6 моделювали одноразовим внутрішньоочеревинним введенням циклофосфаміду у дозі 250 мг/кг. ПЕГ-Філстим або референтний препарат Неуластим вводили одноразово підшкірно в дозі 1 мг/кг через 24 год після ін'єкції циклофоссраміду або через 24 години після ін'єкції 0,9 \% розчину натрію хлориду. На 7-му добу після введення досліджуваного і референтного препаратів тварин наркотизували та відбирали кров на мазок і підрахунок лейкоцитів. Після евтаназії 3 правої стегнової кістки вимивали кістковий мозок, в якому підраховували загальну кількість мієлокаріоцитів, а в мазку кісткового мозку - мієлограму, лейкоеритроцитарне співвідношення, індекс дозрівання нейтрофілів.

Результати й обговорення. У здорових мишей після одноразового застосування ПЕГ-Філстиму або Неуластиму спостерігається збільшення кількості лейкоцитів щодо інтактного контролю. У тварин 3 експериментальною лейкопенією при дії обох препаратів також збільшилась абсолютна кількість лейкоцитів щодо тварин 3 експериментальною патологією. При цьому ефекти ПЕГ-Філстиму та Неуластиму на даний показник статистично значущих відмінностей між собою не мали. Як у здорових мишей, так і у тварин з експериментальною лейкопенією одноразове підшкірне введення препаратів ПЕГ-Філстим або Неуластим збільшує кількість мієлокаріоцитів у кістковому мозку, яке не було пов'язане зі зміною абсолютного вмісту недиференційованих бластів, еозинофрілів, моноцитів і незрілих форм нейтрофрілів. І у здорових тварин, і у мишей з експериментальною патологією після застосування досліджуваного або референтного препаратів спостерігалося збільшення абсолютного вмісту зрілих форм (паличкоядерних і сегментоядерних) нейтрофрілів. Такі зміни призвели до зниження індексу дозрівання нейтрофрілів.

Висновки. Препарат ПЕГ-Філстим в дозі 1 мг/кг має виражений гемостимулюючий ефект як у інтактних мишей, так і у тварин з експериментальною лейкопенією. При дії препарату збільшується кількість лейкоцитів у периферичній крові (за рахунок паличкоядерних нейтрофілів і лімфоцитів), а також збільшується кількість мієлокаріоцитів у кістковому мозку (за рахунок зрілих фрорм нейтрофрілів, базофрілів всіх генерацій, а також еритрокаріоцітів). За своїми характеристиками досліджуваний засіб не поступається референтному препарату Неуластим.
\end{abstract}

Ключові слова: колонієстимулюючі фрактори; фрілграстим; пегфрілграстим; нейтропенія; експериментальна лейкопенія; ПЕГ-Філстим.

Вступ. Нейтропенія -гематологічне ускладнення, яке найчастіше виникає після хіміотерапії у онкологічних хворих, обумовлене ураженням гранулоцитарного паростка і пов'язане з високим ризиком бактеріальної інфекції та розвитком фебрильної нейтропенії [1]. Цей стан супроводжується лихоманкою та становить загрозу для життя пацієнтів, оскільки при неправильному лікуванні може призвести до септичного шоку і смерті. Ступінь і тривалість нейтропенії, що розвивається після хіміотерапії, значною мірою визначає ризик виникнення життєво небезпечних інфрекційних ускладнень. Впровадження у клінічну практику рекомбінантних фрорм природного білка гранулоцитарного колонієстимулюючого фрактора (Г-КСФ) дозволило скоротити тривалість нейтропенії та мінімізувати негативні наслідки мієлосупресивної терапії. На сьогодні доведено ефективність застосування Г-КСФ при лікуванні онкологічних хворих [2, 3]. Порівняльне дослідження ефектів пегфілграстиму і орілграстиму на здорових волонтерах показало, що рівень нейтрофрілів при одноразовому введенні пегфрілграстиму в дозі 60-100 мкг/кг маси тіла в 6-8 разів вищий, ніж при щоденному введенні фрілграстиму в дозі 5-10 мкг/кг. При цьому продукція нейтрофрілів після однократної ін'єкції пегорілграстиму дорівнює продукції гранулоцитів впродовж 10-11-денної терапії орілграстимом. [4].

Пегорілграстим - це Г-КСФ пролонгованої дії, який вводять один раз за цикл хіміотерапії. Дослідження на лабораторних моделях показали, що пег-

ISSN 2312-0967. Pharmaceutical review. 2017. № 4 
Фармакологічні дослідження біологічно активних речовин Pharmacological researches of biologically active substances

фрілграстим має ідентичні 3 нативним фрілграстимом властивості щодо зв'язування з рецептором Г-КСФ, індукції проліферації і диференціювання попередників гранулоцитопоезу, а також стимуляції фрункції зрілих нейтроорілів [5]. Подовжена дія пегорілграстиму зумовлена тим, що ця молекула за рахунок пегилювання (приєднання до N-кінцевої групи метіоніну молекули поліетиленгліколю (ПЕГ) з молекулярною масою 20 kD) практично не підлягає клубочковій фрільтрації в нирках, котра домінує при нейтропенії. Натомість кліренс пегорілграстиму нейтрофрілами, які з високою щільністю експресують рецептор до Г-КСФ, не порушується. Елімінація пегфрілграстиму здійснюється при його зв'язуванні з рецепторами нейтрофрілів [6], що робить цей процес саморегульованим: у період нейтропенії в крові зберігаються високі концентрації препарату, що забезпечує терапевтичний ефект, а із збільшенням кількості нейтрофрілів його концентрація швидко знижується [7].

Мета роботи - дослідити специсрічну фрармакологічну активність препарату ПЕГ-Філстим на моделі оребрильної нейтропенії у мишей.

Матеріали і методи. Оцінку специфрічної фрармакологічної активності препарату ПЕГ-Філстим (ТОВ «Фармацевтичний завод «Біофрарма»», м. Біла Церква, Україна, розчин для ін'єкцій, 10 мг/мл пегорілграстиму) проводили згідно 3 наказом МО3 України № 944 від 14.12.2009 р. «Про погодження матеріалів Порядку проведення доклінічного вивчення лікарських засобів та експертизи матеріалів доклінічного вивчення лікарських засобів» [8]. Піддослідні тварини утримували у віварію згідно із стандартними санітарними нормами, на необхідному харчовому раціоні [9]. Усі дослідження виконані згідно з правилами «Європейської конвенції захисту хребетних тварин, які використовуються в експериментальних та інших наукових цілях» [10]. Експериментальні тварини (самці мишей лінії C57BL/6 масою 17-23 г) були поділені на 6 груп по 10 особин у кожній:

1) інтактні тварини (контроль 1);

2) інтактні тварини + досліджуваний препарат ПЕГ-Філстим;

3) інтактні тварини + референс препарат Неуластим;

4) тварини з експериментальною моделлю лейкопенії (контроль 2);

5) модель лейкопенії + досліджуваний препарат ПЕГ-Філстим;

6) модель лейкопенії + референс препарат Неуластим.

3 метою створення моделі лейкопенії (нейтропенії) мишам одноразово внутрішньоочеревинно вводили циклофоссрамід (Циклофоссран-КМП, Київмедпрепарат, порошок для приготування ін'єкційного розчину у фрлаконах по 0,2 г) у дозі 250 мг/кг [11]. Досліджуваний (ПЕГ-Філстим) або референтний (оригінальний препарат Неуластим, виробництва
Ф. Хоформан-Ля Рош Лтд., Швейцарія) препарати вводили одноразово підшкірно в міжлопаткову ділянку мишей в дозі 1 мг/кг через 24 години після ін'єкції циклофросораміду (групи 5 і 6), або через 24 години після ін'єкції 0,9 \% розчину натрію хлориду з розрахунку об'єму 10 мл/кг (групи 2 і 3). Тваринам групи контроль 1 підшкірно вводили відповідні об'єми 0,9% розчину натрію хлориду. Доза пегорілграстиму 1 мг/кг відповідає експериментальній, яку використовували для підшкірного введення в порівняльному дослідженні впливу фрілграстиму і його пегильованого похідного в інтактних і нейтропенічних мишей [5]. Тому для вивчення специфічної активності препарату ПЕГ-Філстим було обрано саме цю дозу (1 мг/кг).

На 7-му добу після введення досліджуваного і референтного препаратів тварини наркотизували та з орбітального синуса відбирали кров на мазок і підрахунок лейкоцитів. Загальну кількість лейкоцитів та їх морфоологічний склад визначали загальноприйнятими гематологічними методами [12]. Потім тварин піддавали евтаназії методом цервікальної дислокації. 3 правої стегнової кістки вимивали кістковий мозок, в якому підраховували загальну кількість мієлокаріоцитів, а в мазку кісткового мозку - мієлограму, лейко-еритроцитарне співвідношення, індекс дозрівання нейтрофрілів.

Для вивчення клітинності кісткового мозку виділяли стегнову кістку, яку очищали від м'яких тканин, кістковомозковий канал промивали 1 мл 3 \% оцтової кислоти. Отриманий кістковий мозок суспендували в розчині оцтової кислоти шприцом за допомогою голок зі зменшенням діаметра. Загальну кількість мієлокаріоцитів підраховували в камері Горяєва і виражали числом клітин на стегно. Для приготування мазків кісткового мозку вміст стегнової кістки або 1-2 сегментів грудини видавлювали на знежирене скло, розводили ізологічною сироваткою і робили мазок за допомогою шліфованого скла. Висохлі мазки фріксували в метанолі 3-5 хв і фрарбували за Нохта-Максимовим [13]. Мієлограму підраховували на 500 клітин, після чого визначали абсолютний вміст клітинних елементів окремих паростків гемопоезу.

Статистичну обробку результатів проводили за допомогою пакета прикладних програм STATISTICA 6.0 (StatSoft, USA), використовуючи t-критерій Стьюдента та U-критерій Манна-Вітни [14]. Значущими вважали відмінності між контролем і дослідом при р<0,05.

Дослідження було виконано на базі кафредри фрармакології, клінічної фрармакології та фрармакоекономіки ДЗ «Дніпропетровська медична академія» в рамках розробки ТОВ «Фармацевтичний завод «Біофарма»» лікарського засобу ПЕГ-Філстим.

Результати й обговорення. Результати досліджень показали, що у здорових мишей після одноразового підшкірного застосування ПЕГ-Філстиму або Неуластиму спостерігається збільшення кількості лейкоцитів відповідно на 33,9 та 35,4 \% $(p<0,05)$ щодо контролю 1 (табл. 1).

ISSN 2312-0967. Фармацевтичний часопис. 2017. № 4 
Фармакологічні дослідження біологічно активних речовин Pharmacological researches of biologically active substances

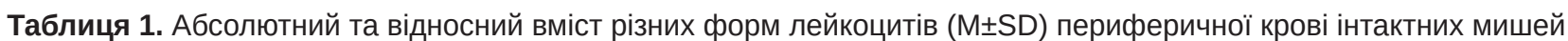
та після одноразового підшкірного введення ПЕГ-Філстиму та Неуластиму

\begin{tabular}{|c|c|c|c|c|}
\hline \multirow{2}{*}{\multicolumn{2}{|c|}{ Показники }} & \multicolumn{3}{|c|}{ Групи тварин } \\
\hline & & \multirow{2}{*}{$\frac{\text { Інтактні, контроль } 1}{6,02 \pm 0,30}$} & \multirow{2}{*}{$\frac{\text { ПЕГ-Філстим, } 1 \text { мг/кг }}{8,06 \pm 0,41^{*}}$} & \multirow{2}{*}{$\frac{\text { Неуластим, } 1 \text { мг/кг }}{8,15 \pm 0,35^{*}}$} \\
\hline Лейкоцити & $\times 10^{9}$ /л & & & \\
\hline \multirow[t]{2}{*}{ Всі нейтрофріли } & $\times 10^{9} / л$ & $1,16 \pm 0,11$ & $1,54 \pm 0,12^{*}$ & $1,53 \pm 0,10^{*}$ \\
\hline & $\%$ & $19,20 \pm 1,36$ & $19,30 \pm 1,48$ & $18,70 \pm 0,83$ \\
\hline \multirow{2}{*}{$\begin{array}{l}\text { Нейтрофріли } \\
\text { (паличкоядерні) }\end{array}$} & $\times 10^{9} / л$ & $0,038 \pm 0,014$ & $0,168 \pm 0,029 *$ & $0,154 \pm 0,028^{*}$ \\
\hline & $\%$ & $0,70 \pm 0,26$ & $2,20 \pm 0,42^{*}$ & $1,90 \pm 0,31^{*}$ \\
\hline \multirow{2}{*}{$\begin{array}{l}\text { Нейтрофріли } \\
\text { (сегментоядерні) }\end{array}$} & $\times 10^{9} / л$ & $1,12 \pm 0,11$ & $1,38 \pm 0,11$ & $1,37 \pm 0,10$ \\
\hline & $\%$ & $18,50 \pm 1,44$ & $17,10 \pm 1,27$ & $16,80 \pm 0,88$ \\
\hline \multirow[t]{2}{*}{ Еозинофріли } & $\times 10^{9} / л$ & $0,142 \pm 0,027$ & $0,148 \pm 0,025$ & $0,123 \pm 0,024$ \\
\hline & $\%$ & $2,40 \pm 0,43$ & $1,80 \pm 0,29$ & $1,50 \pm 0,27$ \\
\hline \multirow[t]{2}{*}{ Лімфоцити } & $\times 10^{9}$ /л & $4,43 \pm 0,27$ & $6,01 \pm 0,36^{*}$ & $6,09 \pm 0,25^{\star}$ \\
\hline & $\%$ & $73,50 \pm 1,89$ & $74,30 \pm 1,49$ & $74,80 \pm 1,00$ \\
\hline \multirow[t]{2}{*}{ Моноцити } & $\times 10^{9} / л$ & $0,290 \pm 0,036$ & $0,363 \pm 0,040$ & $0,412 \pm 0,061$ \\
\hline & $\%$ & $4,90 \pm 0,59$ & $4,60 \pm 0,54$ & $5,00 \pm 0,68$ \\
\hline
\end{tabular}

Примітка: *- p<0,05 щодо контролю 1.

У тварин з експериментальною лейкопенією при дії досліджуваного та рефрерентного препаратів абсолютна кількість лейкоцитів також збільшилась відповідно на 21,9 та 28,1\% ( $<<0,05)$ щодо контролю 2 (табл. 2). При цьому ефекти ПЕГ-Філстиму та Неуластиму на даний показник статистично значущих відмінностей між собою не мали.

Аналіз зміни показників лейкоцитарної формули у здорових та лейкопенічних тварин показав, що збільшення кількості лейкоцитів пов'язане, головним чи- ном, зі зростанням кількості паличкоядерних нейтрофрілів. Так, у здорових мишей після введення ПЕГФілстиму вміст цих фрорм лейкоцитів збільшився на $342,1 \%(p<0,05)$, а після застосування Неуластиму на 305,3 \% $(p<0,05)$ щодо інтактного контролю (див. табл. 1). У тварин з експериментальною лейкопенією таке збільшення становило відповідно 284,9 та $313,2 \%(p<0,05)$ щодо контролю 2 (табл. 2). Крім того, при дії обох препаратів як у здорових тварин, так і у мишей з експериментальною лейкопенією спо-

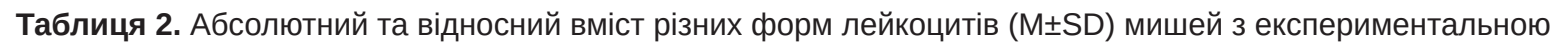
лейкопенією (ЕЛ) та після одноразового підшкірного введення ПЕГ-Філстиму та Неуластиму

\begin{tabular}{|c|c|c|c|c|}
\hline \multirow{2}{*}{\multicolumn{2}{|c|}{ Показники }} & \multicolumn{3}{|c|}{ Групи тварин } \\
\hline & & \multirow{2}{*}{$\begin{array}{c}\text { ЕЛ, контроль } 2 \\
3,52 \pm 0,24\end{array}$} & \multirow{2}{*}{$\begin{array}{c}\text { ЕЛ+ } \\
\text { ПЕГ-Філстим, } 1 \text { мг/кг } \\
4,29 \pm 0,22^{*}\end{array}$} & \multirow{2}{*}{$\begin{array}{c}\text { ЕЛ+ } \\
\text { Неуластим, } 1 \text { мг/кг } \\
4,51 \pm 0,26^{\star}\end{array}$} \\
\hline Лейкоцити & $\times 10^{9} / л$ & & & \\
\hline \multirow{2}{*}{ Всі нейтрофріли } & $\times 10^{9} / л$ & $0,97 \pm 0,06$ & $1,21 \pm 0,08^{*}$ & $1,36 \pm 0,12^{*}$ \\
\hline & $\%$ & $27,90 \pm 1,20$ & $28,40 \pm 1,48$ & $30,00 \pm 1,56$ \\
\hline \multirow{2}{*}{$\begin{array}{l}\text { Нейтросріли } \\
\text { (паличкоядерні) }\end{array}$} & $\times 10^{9} / \pi$ & $0,053 \pm 0,008$ & $0,204 \pm 0,033^{*}$ & $0,219 \pm 0,030^{*}$ \\
\hline & $\%$ & $1,60 \pm 0,27$ & $4,70 \pm 0,73^{*}$ & $4,90 \pm 0,57^{*}$ \\
\hline \multirow{2}{*}{$\begin{array}{l}\text { Нейтрофріли } \\
\text { (сегментоядерні) }\end{array}$} & ×109/л & $0,92 \pm 0,06$ & $1,01 \pm 0,06$ & $1,15 \pm 0,11$ \\
\hline & $\%$ & $26,30 \pm 1,10$ & $23,70 \pm 1,27$ & $25,10 \pm 1,51$ \\
\hline \multirow{2}{*}{ Еозинофріли } & $\times 10^{9} / л$ & $0,112 \pm 0,016$ & $0,134 \pm 0,019$ & $0,143 \pm 0,017$ \\
\hline & $\%$ & $3,20 \pm 0,39$ & $3,10 \pm 0,38$ & $3,20 \pm 0,33$ \\
\hline \multirow{2}{*}{ Лімсроцити } & $\times 10^{9} / л$ & $2,01 \pm 0,16$ & $2,41 \pm 0,14$ & $2,45 \pm 0,13$ \\
\hline & $\%$ & $56,70 \pm 1,65$ & $56,20 \pm 2,00$ & $54,70 \pm 1,68$ \\
\hline \multirow{2}{*}{ Моноцити } & $\times 10^{9} / \pi$ & $0,425 \pm 0,033$ & $0,535 \pm 0,054$ & $0,549 \pm 0,060$ \\
\hline & $\%$ & $12,20 \pm 0,70$ & $12,30 \pm 0,82$ & $12,10 \pm 0,92$ \\
\hline
\end{tabular}

Примітка: * - p<0,05 щодо контролю 2.

ISSN 2312-0967. Pharmaceutical review. 2017. № 4 
Фармакологічні дослідження біологічно активних речовин Pharmacological researches of biologically active substances

стерігали тенденцію до підвищення кількості сегментоядерних (зрілих фрорм) нейтрофрілів у периферичній крові (табл. 1, 2), проте статистично вірогідними ці зміни не були. Слід зазначити, що у здорових тварин, які отримували як досліджуваний, так і референтний препарати, було зафріксовано збільшення абсолютної кількості лімфроцитів щодо інтактного контролю (відповідно на 35,7 та 37,5 \%; р<0,05). Натомість у мишей з експериментальною лейкопенією спостерігалась тенденція до зростання кількості лімфоцитів - на 19,9 \% (р>0,05) при дії ПЕГ-Філстиму та на 21,9 \% (p>0,05) при дії Неуластиму щодо контролю 2, проте ці зміни не були статистично вірогідними. Обидва препарати не призводили до значущих змін кількості еозинофрілів і моноцитів в периферичній крові експериментальних тварин (табл. 1, 2).
Як свідчать результати наших досліджень, як у здорових мишей, так і у тварин з експериментальною лейкопенією одноразове підшкірне введення препаратів ПЕГ-Філстим або Неуластим збільшує кількість мієлокаріоцитів в кістковому мозку (табл. 3, 4). При цьому таке збільшення не було пов'язане зі зміною абсолютного вмісту недиференційованих бластів, еозиносрілів, моноцитів і незрілих фрорм нейтрофрілів.

Натомість і у здорових тварин, і у мишей з експериментальною патологією після застосування досліджуваного або рефрерентного препаратів спостерігалося збільшення абсолютного вмісту зрілих фрорм (паличкоядерних і сегментоядерних) нейтрофрілів (табл. 3, 4). Такі зміни призвели до зниження індексу дозрівання нейтрофрілів.

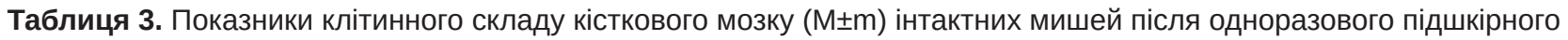
введення ПЕГ-Філстиму та Неуластиму

\begin{tabular}{|c|c|c|c|c|}
\hline \multirow{2}{*}{\multicolumn{2}{|c|}{ Показники }} & \multicolumn{3}{|c|}{ Групи тварин } \\
\hline & & \multirow{2}{*}{$\begin{array}{c}\text { Інтактні, контроль } 1 \\
13,36 \pm 0,45\end{array}$} & \multirow{2}{*}{$\begin{array}{c}\text { ПЕГ-Філстим, } \\
1 \text { мг/кг } \\
16,40 \pm 0,64^{*}\end{array}$} & \multirow{2}{*}{$\frac{\text { Неуластим, } 1 \text { мг/кг }}{16,23 \pm 0,48^{*}}$} \\
\hline Мієлокаріоцити & $\times 10^{6} /$ стегно & & & \\
\hline Недисеренційовані бласти & $\times 10^{6} /$ стегно & $0,081 \pm 0,022$ & $0,036 \pm 0,002$ & $0,032 \pm 0,001$ \\
\hline \multirow[t]{2}{*}{ Промієлоцити } & $\times 10^{6} /$ стегно & $0,74 \pm 0,06$ & $0,20 \pm 0,02^{\star}$ & $0,20 \pm 0,01^{*}$ \\
\hline & $\%$ & $5,52 \pm 0,38$ & $1,22 \pm 0,11^{*}$ & $1,26 \pm 0,07^{*}$ \\
\hline \multirow[t]{2}{*}{ Мієлоцити } & ×106/стегно & $1,16 \pm 0,09$ & $0,87 \pm 0,05^{\star}$ & $0,83 \pm 0,06^{\star}$ \\
\hline & $\%$ & $8,62 \pm 0,46$ & $5,34 \pm 0,32^{*}$ & $5,10 \pm 0,39^{*}$ \\
\hline \multirow[t]{2}{*}{ Метамієлоцити } & $\times 10^{6} /$ стегно & $1,44 \pm 0,10$ & $1,43 \pm 0,10$ & $1,40 \pm 0,12$ \\
\hline & $\%$ & $10,82 \pm 0,66$ & $8,68 \pm 0,49 *$ & $8,58 \pm 0,67^{*}$ \\
\hline \multirow[t]{2}{*}{ Нейтрофріли (паличкоядерні) } & $\times 10^{6} /$ стегно & $3,51 \pm 0,15$ & $4,95 \pm 0,18^{*}$ & $4,97 \pm 0,28^{*}$ \\
\hline & $\%$ & $26,42 \pm 1,15$ & $30,30 \pm 0,67^{*}$ & $30,58 \pm 1,29 *$ \\
\hline \multirow[t]{2}{*}{ Нейтрофріли (сегментоядерні) } & $\times 10^{6} /$ стегно & $1,05 \pm 0,06$ & $3,16 \pm 0,24^{*}$ & $3,22 \pm 0,23^{*}$ \\
\hline & $\%$ & $7,88 \pm 0,47$ & $19,18 \pm 1,17^{*}$ & $19,78 \pm 1,19 *$ \\
\hline \multirow[t]{2}{*}{ Еозинофріли } & $\times 10^{6} /$ стегно & $0,480 \pm 0,042$ & $0,514 \pm 0,073$ & $0,587 \pm 0,041$ \\
\hline & $\%$ & $3,62 \pm 0,33$ & $3,10 \pm 0,42$ & $3,60 \pm 0,21$ \\
\hline \multirow[t]{2}{*}{ Базофріли } & $\times 10^{6} /$ стегно & $0,029 \pm 0,006$ & $0,078 \pm 0,008^{*}$ & $0,068 \pm 0,008^{*}$ \\
\hline & $\%$ & $0,220 \pm 0,047$ & $0,480 \pm 0,053^{*}$ & $0,420 \pm 0,047^{*}$ \\
\hline \multirow[t]{2}{*}{ Еритрокаріоцити } & $\times 10^{6} /$ стегно & $3,84 \pm 0,25$ & $4,67 \pm 0,28^{*}$ & $4,49 \pm 0,18^{*}$ \\
\hline & $\%$ & $28,54 \pm 1,07$ & $28,44 \pm 1,21$ & $27,80 \pm 1,22$ \\
\hline \multirow[t]{2}{*}{ Лімфоцити } & ×10\%/стегно & $0,87 \pm 0,06$ & $0,34 \pm 0,03^{*}$ & $0,27 \pm 0,03^{*}$ \\
\hline & $\%$ & $6,54 \pm 0,47$ & $2,06 \pm 0,13^{*}$ & $1,64 \pm 0,20^{*}$ \\
\hline \multirow[t]{2}{*}{ Моноцити } & $\times 10^{6} /$ стегно & $0,153 \pm 0,018$ & $0,160 \pm 0,016$ & $0,168 \pm 0,013$ \\
\hline & $\%$ & $1,18 \pm 0,15$ & $0,98 \pm 0,09$ & $1,04 \pm 0,08$ \\
\hline Незрілі нейтрофріли & ×10\%/стегно & $3,35 \pm 0,18$ & $2,50 \pm 0,16^{*}$ & $2,43 \pm 0,14^{*}$ \\
\hline Зрілі нейтрофріли & $\times 10^{6} /$ стегно & $4,56 \pm 0,16$ & $8,11 \pm 0,35^{\star}$ & $8,19 \pm 0,37^{*}$ \\
\hline \multicolumn{2}{|l|}{ Індекс дозрівання нейтрофрілів } & $0,740 \pm 0,043$ & $0,310 \pm 0,018^{*}$ & $0,300 \pm 0,020^{*}$ \\
\hline \multicolumn{2}{|c|}{ Лейко-еритробластичне співвідношення } & $2,53 \pm 0,13$ & $2,56 \pm 0,15$ & $2,65 \pm 0,15$ \\
\hline
\end{tabular}

Примітка: * - p <0,05 щодо контролю 1.

ISSN 2312-0967. Фармацевтичний часопис. 2017. № 4 
Фармакологічні дослідження біологічно активних речовин Pharmacological researches of biologically active substances

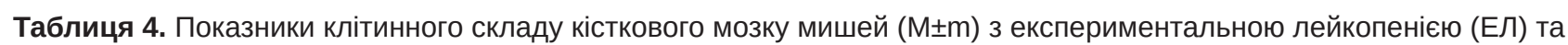
після одноразового підшкірного введення ПЕГ-Філстиму та Неуластиму

\begin{tabular}{|c|c|c|c|c|}
\hline \multirow{2}{*}{\multicolumn{2}{|c|}{ Показники }} & \multicolumn{3}{|c|}{ Групи тварин } \\
\hline & & \multirow{2}{*}{$\begin{array}{c}\text { ЕЛ, контроль } 2 \\
11,31 \pm 0,41\end{array}$} & \multirow{2}{*}{$\begin{array}{c}\text { ЕЛ+ПЕГ-Філстим, } \\
1 \text { мг/кГ } \\
15,44 \pm 0,58^{*}\end{array}$} & \multirow{2}{*}{$\begin{array}{c}\text { ЕЛ+ } \\
\text { Неуластим, } 1 \text { мг/кг } \\
15,97 \pm 0,94^{*}\end{array}$} \\
\hline Мієлокаріоцити & ×106/стегно & & & \\
\hline Недифреренційовані бласти & ×106/стегно & $0,370 \pm 0,017$ & $0,521 \pm 0,012$ & $0,504 \pm 0,027$ \\
\hline \multirow{2}{*}{ Промієлоцити } & ×106/стегно & $0,39 \pm 0,06$ & $0,18 \pm 0,01^{*}$ & $0,20 \pm 0,02^{*}$ \\
\hline & $\%$ & $3,42 \pm 0,48$ & $1,14 \pm 0,06^{*}$ & $1,26 \pm 0,05^{\star}$ \\
\hline \multirow{2}{*}{ Мієлоцити } & ×10\%/стегно & $0,83 \pm 0,04$ & $0,36 \pm 0,02^{*}$ & $0,35 \pm 0,02^{*}$ \\
\hline & $\%$ & $7,35 \pm 0,21$ & $2,32 \pm 0,09 *$ & $2,18 \pm 0,06^{*}$ \\
\hline \multirow{2}{*}{ Метамієлоцити } & ×10\%/стегно & $0,78 \pm 0,04$ & $1,41 \pm 0,08^{*}$ & $1,54 \pm 0,11^{*}$ \\
\hline & $\%$ & $6,88 \pm 0,21$ & $9,10 \pm 0,24^{*}$ & $9,64 \pm 0,38^{*}$ \\
\hline \multirow{2}{*}{ Нейтрофріли (паличкоядерні) } & ×106/стегно & $2,58 \pm 0,13$ & $4,28 \pm 0,27^{*}$ & $4,70 \pm 0,37^{\star}$ \\
\hline & $\%$ & $26,74 \pm 0,54$ & $27,52 \pm 0,92^{\star}$ & $29,17 \pm 0,89 *$ \\
\hline \multirow{2}{*}{ Нейтрофріли (сегментоядерні) } & ×10\%/стегно & $1,01 \pm 0,05$ & $1,47 \pm 0,08^{*}$ & $1,44 \pm 0,09 *$ \\
\hline & $\%$ & $9,06 \pm 0,50$ & $9,48 \pm 0,27$ & $9,04 \pm 0,23$ \\
\hline \multirow{2}{*}{ Еозинофріли } & ×106/стегно & $0,234 \pm 0,012$ & $0,332 \pm 0,013^{*}$ & $0,348 \pm 0,022^{*}$ \\
\hline & $\%$ & $2,08 \pm 0,10$ & $2,16 \pm 0,07$ & $2,19 \pm 0,07$ \\
\hline \multirow{2}{*}{ Базофріли } & ×106/стегно & $0,013 \pm 0,001$ & $0,052 \pm 0,003^{*}$ & $0,054 \pm 0,003^{*}$ \\
\hline & $\%$ & $0,120 \pm 0,013$ & $0,340 \pm 0,016^{*}$ & $0,350 \pm 0,027^{*}$ \\
\hline \multirow{2}{*}{ Еритрокаріоцити } & ×10\%/стегно & $1,19 \pm 0,11$ & $1,74 \pm 0,11^{*}$ & $1,79 \pm 0,11^{*}$ \\
\hline & $\%$ & $10,42 \pm 0,69$ & $11,16 \pm 0,36$ & $11,32 \pm 0,42$ \\
\hline \multirow{2}{*}{ Лімсроцити } & ×106/стегно & $0,49 \pm 0,03$ & $0,25 \pm 0,02 *$ & $0,33 \pm 0,02^{*}$ \\
\hline & $\%$ & $4,30 \pm 0,22$ & $1,64 \pm 0,09 *$ & $2,08 \pm 0,07^{*}$ \\
\hline \multirow{2}{*}{ Моноцити } & ×10\%/стегно & $0,078 \pm 0,007$ & $0,159 \pm 0,012^{*}$ & $0,158 \pm 0,016^{*}$ \\
\hline & $\%$ & $0,70 \pm 0,07$ & $1,04 \pm 0,08^{*}$ & $1,02 \pm 0,12^{*}$ \\
\hline Незрілі нейтрофріли & ×10\%/стегно & $2,00 \pm 0,11$ & $1,95 \pm 0,10$ & $2,09 \pm 0,14$ \\
\hline Зрілі нейтрофріли & $\times 10^{6} /$ стегно & $3,60 \pm 0,15$ & $5,74 \pm 0,32^{*}$ & $6,15 \pm 0,46^{*}$ \\
\hline \multicolumn{2}{|l|}{ Індекс дозрівання нейтрофрілів } & $0,559 \pm 0,026$ & $0,340 \pm 0,007^{*}$ & $0,344 \pm 0,012^{*}$ \\
\hline \multicolumn{2}{|c|}{ Лейкоеритробластичне співвідношення } & $5,63 \pm 0,34$ & $4,94 \pm 0,16$ & $5,12 \pm 0,29$ \\
\hline
\end{tabular}

Примітка: * - p < 0,05 щодо контролю 2.

Збільшення кількості мієлокаріоцитів зумовлене зростанням кількості базофрілів всіх генерацій. Крім збільшення в кістковому мозку кількості клітин-попередників гранулоцитарного ряду, під дією препаратів Г-КСФ спостерігалося також помірне зростання кількості еритрокаріоцитів. У результаті цього лейкоеритробластичне співвідношення в групах досліджуваного і рефрерентного препаратів залишалося на рівні контролю.
Висновки. Препарат ПЕГ-Філстим в дозі 1 мг/кг має виражений гемостимулюючий ефект як у інтактних мишей лінії C57BL/6, так і у тварин з експериментальною лейкопенією. При дії препарату збільшується кількість лейкоцитів у периферичній крові (за рахунок паличкоядерних нейтрофрілів і лімфоцитів), а також збільшується кількість мієлокаріоцитів у кістковому мозку (за рахунок зрілих фрорм нейтрофілів, базофілів всіх генерацій, а також еритрокаріоцитів). За характеристиками досліджуваний засіб не поступається рефрерентному препарату Неуластим.

ISSN 2312-0967. Pharmaceutical review. 2017. № 4 
Фармакологічні дослідження біологічно активних речовин Pharmacological researches of biologically active substances

\title{
ЭКСПЕРИМЕНТАЛЬНОЕ ИССЛЕДОВАНИЕ СПЕЦИФИЧЕСКОЙ ФАРМАКОЛОГИЧЕСКОЙ АКТИВНОСТИ ПРЕПАРАТА ПЭГ-ФИЛСТИМ
}

\author{
В. Л. Карбовский, И. А. Шевчук, О. В. Куркина \\ ООО «Фармацевтический завод «Биофрарма»», Белая Церковь \\ publication@biofarma.ua
}

Цель работы. Исследовать специфическую фрармакологическую активность препарата ПЭГ-Филстим на модели фебрильной нейтропении у мышей.

Материалы и методы. С целью создания модели лейкопении (нейтропении) самцам мышей линии C57BL/6 однократно внутрибрюшинно вводили циклофосфамид в дозе 250 мг/кг. ПЭГ-Филстим или референтный препарат Неуластим вводили однократно подкожно в дозе 1 мг/кг через 24 ч после инъекции циклофросфрамида или через 24 часа после инъекции 0,9 \% раствора натрия хлорида. На седьмой день после введения исследуемого и референтного препаратов животных наркотизировали и отбирали кровь на мазок и подсчет лейкоцитов. После эвтаназии из правой бедренной кости вымывали костный мозг, в котором подсчитывали общее количество миелокариоцитов, а в мазке костного мозга - миелограмму, лейкоэритроцитарное соотношение, индекс созревания нейтрофрилов.

Результаты и обсуждение. У здоровых мышей после однократного применения ПЭГ-Филстима или Неуластима наблюдается увеличение количества лейкоцитов относительно интактного контроля. У животных с экспериментальной лейкопенией при действии обоих препаратов абсолютное количество лейкоцитов также увеличилось относительно контроля 2 (животные с экспериментальной патологией). При этом эффекты ПЭГФилстима и Неуластима на данный показатель статистически значимых различий между собой не имели. Как у здоровых мышей, так и у животных с экспериментальной лейкопенией однократное подкожное введение препаратов ПЭГ-Филстим или Неуластим увеличивает количество миелокариоцитив в костном мозге, которое не было связано с изменением абсолютного содержания недифреренцированных бластов, эозиносрилов, моноцитов и незрелых фрорм нейтрофилов. В свою очередь, и у здоровых животных, и у мышей с экспериментальной патологией после применения исследуемого или референтного препаратов наблюдалось увеличение абсолютного содержания зрелых форм (палочкоядерных и сегментоядерных) нейтрофилов. Такие изменения привели к снижению индекса созревания нейтрофилов.

Выводы. Препарат ПЭГ-Филстим в дозе 1 мг/кг обладает выраженным гемостимулирующим эфффектом как у интактных мышей, так и у животных с экспериментальной лейкопенией. При действии препарата увеличивается количество лейкоцитов в периферической крови (за счет палочкоядерных нейтрофилов и лимфоцитов), а также увеличивается количество миелокариоцитив в костном мозге (за счет зрелых фрорм нейтрофилов, базофилов всех поколений, а также еритрокариоцитов). По своим характеристикам исследуемое средство не уступает ресрерентному препарату Неуластим.

Ключевые слова: колониестимулирующие фракторы; фрилграстим; пэгфрилграстим; нейтропения; экспериментальная лейкопения; ПЭГ-Филстим.

\section{EXPERIMENTAL STUDY OF THE SPECIFIC PHARMACOLOGICAL ACTIVITY OF THE DRUG PEG- FILSTIM}

\author{
V. L. Karbovskyy, I. A. Shevchuk, O. V. Kurkina \\ LLC «Pharmaceutical Plant «Biopharma»», Bila Tserkva, Ukraine \\ publication@biofarma.ua
}

The aim of the work. Studying the specific pharmacological activity of the drug PEG-Filstim on the febrile neutropenia model in mice.

Materials and Methods. Experimental leukopenia in male C57BL/6 mice was modeled by single intraventricular administration of cyclophosphamide at a dose of $250 \mathrm{mg} / \mathrm{kg}$. PEG-Filstim or reference drug Neulastim were administered subcutaneously once in the dose of $1 \mathrm{mg} / \mathrm{kg} 24$ hours after the injection of cyclophosphamide, or 24 hours after the injection of $0.9 \%$ sodium chloride solution. On the 7 th day after administration of studied and reference drugs, the animals were anesthetized and blood from the orbital sinus was collected for smear preparation and white blood cells counting. After euthanasia of animals the marrow from the right thigh-bone was washed-out, and general number of myelocariocytes was counted. A myelogram, leukocyte: erythrocyte ratio and neutrophil maturation index were counted in the bone marrow smear.

ISSN 2312-0967. Фармацевтичний часопис. 2017. № 4 
Results and Discussion. The results of the study has shown, that in healthy mice after single subcutaneous administration of PEG-Filstim or Neulastim an increase in the number of white blood cells is observed, as compared to the intact controls. In the animals with experimental leukopenia, under action of the studied and reference drugs the absolute number of leukocytes also increased, as compared to the control 2 (animals with experimental pathology). Furthermore, the effects of PEG-Filstim or Neulastim on this parameter did not have statistically significant differences. As the results of our studies show, both in healthy mice and in the animals with experimental leukopenia, single administration of the drugs PEG-Filstim or Neulastim increases the number of the myelocariocytes in the bone marrow. Incidentally, this increase was not in relation with changes in the absolute content of undifferentiated blasts, eosinophils, monocytes and immature forms of neutrophils. Both in healthy mice and in the animals with experimental pathology, after administration of the studied or reference drugs an increase was observed in absolute content of mature forms (bands and segments) of neutrophils. Those changes resulted in a decrease in neutrophil maturation index.

Conclusions. The drug PEG-Filstim at the dose of $1 \mathrm{mg} / \mathrm{kg}$ possesses a pronounced hemostimulative effect both in intact mice, and in animals with experimental leukopenia. Under the action of the drug, the number of white blood cells in peripheral blood increases (by increasing the number of band neutrophils and lymphocytes), and also increases the number of myelocariocytes in the bone marrow (by increasing the number of mature neutrophils, basophils of all generations, and erythrocariocytes). By its characteristics, the studied drug is highly competitive with the reference product Neulastim.

Key words: colony stimulating factors; filgrastim; pegfilgrastim; neutropenia; experimental leucopenia; PEG-Filstim.

\section{Список літератури}

1. Klastersky J. Current attitudes for therapy of febrile neutropenia with consideration to cost-effectiveness / J. Klastersky // Curr. Op. In Oncol. - 1998. - Vol. 10. - P. 284-290.

2. Impact of primary prophylaxis with granulocyte colonystimulating factor on febrile neutropenia and mortality in adult cancer patients receiving chemotherapy: a systematic review / N. Kuderer, D. Dale, J. Crawford., G. Lyman // J. Clin. Oncol. - 2007. - Vol. 25. - P. 3158-6731.

3. Kubo K. A randomized, double-blind trial of pegfilgrastim versus filgrastim for the management of neutropenia during CHASE(R) chemotherapy for malignant lymphoma / K. Kubo, Y. Miyazaki, T. Murayama [et al.] // Br. J. Haematol. - 2016. - Vol. 174 (4). - P. 563-570.

4. Holmes F. A. Comparable efficacy and safety profiles of once-per-cycle pegfilgrastim and daily injection filgrastim in hemotherapy-induced neutropenia: a multicenter dosefinding study in women with breast cancer/ F. A. Holmes, S. E. Jones, J. O'Shaughnessy [et al.] // Ann. Oncol. 2002. - Vol. 13 (6). - P. 903-909.

5 . Lord B. I. Kinetics of neutrophils production in normal and neutropenic animals during the response to filgrastim ( $r$ metHuG-CSF) or filgrastim SD/01 (PEG-r-metHuG-CSF) / B. I. Lord, L. B. Woolford, G. Molineux // Clin. Cancer Res. - 2001. - Vol. 7. - P. 2085-2090.

6. Yang B. B. Pharmacokinetics and pharmacodynamics of pegfilgrastim / B. B. Yang, A. Kido // Clin. Pharmacokinet. 2011. - Vol. 50(5). - P. 295-306.

\section{References}

1. Klastersky J. Current attitudes for therapy of febrile neutropenia with consideration to cost-effectiveness. Curr Op in Oncol. 1998;10: 284-90.

2. Kuderer N, Dale D, Crawford J, Lyman G. Impact of primary prophylaxis with granulocyte colony-stimulating factor on febrile neutropenia and mortality in adult cancer patients receiving chemotherapy: a systematic review. J Clin Oncol. 2007;25: 3158-6731.
7. Molineux G. Pegfilgrastim: using pegylation technology to improve neutropenia support in cancer patients / G. Molineux // Anticancer. Drugs. - 2003. - Vol. 14. - P. 259-264. 8. Порядок проведення доклінічного вивчення лікарських засобів та експертизи матеріалів доклінічного вивчення лікарських засобів : наказ МОЗ України № 944 від 14.12.2009 p.

9. Настанова СТ-НМОЗУ 42-6.0:2008. Лікарські засоби. Належна лабораторна практика (видання офріційне). I [Стефранов О., Бухтіарова Т., Коваленко В. та ін.]. - К. : Моріон, 2009. - С. 37-68.

10. European convention for the protection of vertebrate animals used for experimental and other scientific purpose: Council of Europe 18.03.1986. - Strasbourg, 1986. - 52 p. 11. Bucklin S. E. Bacteremia versus Endotoxemia in Experimental Mouse Leukopenia - Role of Antibiotic Chemotherapy / S. E. Bucklin, D. C. Morrison // J. Infect. Dis. 1996. - Vol. 174. - P. 1249-1254.

12. Лабораторные исследования в клинике / Под ред. В. В. Меньшикова. - М. : Медицина, 1987. - 365 с.

13. Гольдберг Е. Д. Противоопухолевые антибиотики антрациклинового ряда и система крови / Е. Д. Гольдберг, В. В. Новицкий. - Томск, 1986. - 240 с.

14. Реброва О. Ю. Статистический анализ медицинских данных. Применение пакета прикладных программ STATISTICA / О. Ю. Реброва - 3-е изд. - М. : МедиаСфера, 2006. -312 c.

3. Kubo K, Miyazaki Y, Murayama T, Shimazaki R, Usui N, Urabe A, Hotta T, Tamura K. A randomized, double-blind trial of pegfilgrastim versus filgrastim for the management of neutropenia during CHASE(R) chemotherapy for malignant lymphoma. Br J Haematol. 2016;174(4): 570.

4. Holmes FA, Jones SE, O'Shaughnessy J, Vukelja S, George T, Savin M, et al. Comparable efficacy and safety profiles of once-per-cycle pegfilgrastim and daily injection

ISSN 2312-0967. Pharmaceutical review. 2017. № 4 
Фармакологічні дослідження біологічно активних речовин Pharmacological researches of biologically active substances

filgrastim in hemotherapy-induced neutropenia: a multicenter dose-finding study in women with breast. Ann Oncol. 2002; 13(6): 903-9.

5. Lord BI, Woolford LB, Molineux G. Kinetics of neutrophils production in normal and neutropenic animals during the response to filgrastim ( $r$-metHuG-CSF) or filgrastim SD/01 (PEG-r-metHuG-CSF)/ Clin Cancer Res. 2001;7: 2085-90. 6. Yang BB, Kido A. Pharmacokinetics and pharmacodynamics of pegfilgrastim. Clin Pharmacokinet. 2011;50(5): 295-306.

7. Molineux G. Pegfilgrastim: using pegylation technology to improve neutropenia support in cancer patients. Anticancer Drugs. 2003;14: 259-64.

8. Order of the Ministry of Health of Ukraine No. 944 dated December 14, 2009 "Procedure for conducting preclinical study of medicinal products and examination of materials for preclinical study of medicinal products" [Наказ МО3 України № 944 від 14.12.2009 р. «Порядок проведення доклінічного вивчення лікарських засобів та експертизи матеріалів доклінічного вивчення лікарських засобів»]. Ukrainian.

9. Stefanov O, Buhtiarova T, Kovalenko VE. Instruction CT-
NMOSU 42-6.0: 2008. Medicines. Good laboratory practice (official publication) [Настанова СТ-НМОЗУ 42-6.0:2008. Лікарські засоби. Належна лабораторна практика (видання офріційне)]. Kyiv: Morion, 2009. Ukrainian.

10. European convention for the protection of vertebrate animals used for experimental and other scientific purpose: Council of Europe 18.03.1986. - Strasbourg, 1986. - 52 p. 11. Bucklin SE, Morrison DC. Bacteremia versus endotoxemia in experimental mouse leukopenia - role of antibiotic chemotherapy. J Infect Dis. 1996;174: 1249-54.

12. Menshikov VV. Redactor. Laboratory research in the clinic [Лабораторные исследования в клинике] Moscow: Meditsina, 1987. Russian.

13. Goldberg ED, Novitskiy VV. Antitumor antibiotics anthracycline and blood system [Противоопухолевые антибиотики антрациклинового ряда и система крови] Tomsk, 1986. Russian.

14. Rebrova OYu. Statistical analysis of medical data. Application of a package of applied programs STATISTICA [Статистический анализ медицинских данных. Применение пакета прикладных программ STATISTICA] 3rd ed. - Moscow: MediaSphere, 2006. Russian

Отримано 02.10.2017

ISSN 2312-0967. Фармацевтичний часопис. 2017. № 4 